\title{
New insights into the antimicrobial mechanisms of copper touch surfaces
}

\author{
B Keevil', S Warnes \\ From International Conference on Prevention \& Infection Control (ICPIC 2011) \\ Geneva, Switzerland. 29 June - 2 July 2011
}

\section{Introduction / objectives}

Survival of pathogens on touch surfaces contributes to increasing incidence and spread of antibiotic resistance and infection in hospitals. One way to address this could be to use biocidal surfaces in conjunction with improved cleaning regimes. Exposure to moist copper alloy surfaces, to simulate fomite contamination, resulted in a rapid kill of significant bacterial, viral and fungal pathogens. We now report studies on dry surfaces with a range of pathogens to elucidate the antimicrobial mechanism.

\section{Methods}

Clinical isolates of VRE, MRSA, E. coli O157, A. baumannii and Salmonella were inoculated onto copper alloy and stainless steel surfaces. Survivors were assessed by culture on agar media, respiration using CTC reduction, membrane potential using Rhodamine 123 and cell membrane integrity using BacLight stain. Genomic and plasmid DNA integrity was determined using gel electrophoresis and a sensitive genomic fragmentation assay. Contribution of $\mathrm{Cu}(\mathrm{I})$ or $\mathrm{Cu}(\mathrm{II})$ ions, and superoxide or hydroxyl free radical to the antimicrobial effect was determined by the protective effect of copper chelators and reactive oxygen species quenchers.

\section{Results}

Copper surface toxicity in enterococci and MRSA involved $\mathrm{Cu}(\mathrm{I})$ and $(\mathrm{Cu}(\mathrm{II})$ ion release and generation of superoxide, resulting in rapid collapse of membrane potential, arrested respiration and DNA breakdown. Fenton reaction generation of hydroxyl radicals was more important in Gram-negative bacteria and this was also accompanied by a compromised cell membrane.

School of Biological Sciences, University of Southampton, Southampton, UK

\section{Conclusion}

Contact surfaces containing copper could be useful to help prevent spread of viable pathogens. The rapid destruction of genomic and plasmid nucleic acid could prevent mutational resistance developing and also help reduce the spread of antibiotic resistance genes to receptive and potentially more virulent organisms, as well as genes responsible for virulence.

\section{Disclosure of interest}

B. Keevil Grant/Research support from International Copper Association, S. Warnes Grant/Research support from International Copper Association.

\section{Published: 29 June 2011}

\section{doi:10.1186/1753-6561-5-S6-P39}

Cite this article as: Keevil and Warnes: New insights into the antimicrobial mechanisms of copper touch surfaces. BMC Proceedings 2011 5(Suppl 6):P39.
Submit your next manuscript to BioMed Central and take full advantage of:

- Convenient online submission

- Thorough peer review

- No space constraints or color figure charges

- Immediate publication on acceptance

- Inclusion in PubMed, CAS, Scopus and Google Scholar

- Research which is freely available for redistribution
C Biomed Central

\section{Biomed Central}

